\title{
The Economic Impact of the Lockdown Due to COVID-19 Pandemic on Low Income Households of the Five Divisions of Kampala District in Uganda
}

\author{
Richard Wemesa $^{1,2,3 *}$, Christopher Wagima ${ }^{1,4}$, Ivan Bakaki ${ }^{1,4}$, Dickson Turyareeba ${ }^{1,5}$ \\ ${ }^{1}$ College of Business and Law, King Ceasor University, Kampala, Uganda \\ ${ }^{2}$ The Uganda Institute of Banking \& Financial Services, Kampala, Uganda \\ ${ }^{3}$ UNICAF University, Larnaca, Cyprus \\ ${ }^{4}$ Faculty of Business \& Management, International University of East Africa, Kampala, Uganda \\ ${ }^{5}$ Makerere University Business School, Kampala, Uganda \\ Email: ^Richie.wemesa@gmail.com, ^r.wemesa@uganda.unicaf.org, chriswagima@gmail.com, bakakiivan2012@gmail.com, \\ dturyareba@mubs.ac.ug
}

How to cite this paper: Wemesa, R., Wagima, C., Bakaki, I., \& Turyareeba, D. (2020). The Economic Impact of the Lockdown Due to COVID-19 Pandemic on Low Income Households of the Five Divisions of Kampala District in Uganda. Open Journal of Business and Management, 8, 1560-1566. https://doi.org/10.4236/ojbm.2020.84099

Received: May 8, 2020

Accepted: July 10, 2020

Published: July 13, 2020

Copyright $\odot 2020$ by author(s) and Scientific Research Publishing Inc. This work is licensed under the Creative Commons Attribution International License (CC BY 4.0).

http://creativecommons.org/licenses/by/4.0/

\begin{abstract}
The impact of the nationwide lockdown due to COVID-19 pandemic is causing tremendous and continuing hardships to low income Ugandans specifically the casual worker's section that earns and spends on a daily basis. Households in the lowest income brackets are the hardest hit, due to inconsistency in income streams of these household breadwinners and the inelastic nature of basic expenditure of these households. The government has been providing food relief support packages of posho and beans to this section of Ugandans starting with residents of Bwaise, a suburb in Kawempe Division of the capital Kampala. The government has also appealed to well off Ugandans to donate food relief packages to the COVID-19 national task force to ensure food relief donations continue throughout the whole specifically to the hard hit areas because the duration of the food support relief cannot be estimated now but it will depend on how long the lockdown situation will remain and what rate of normalization is in the coming days after lifting of the lockdown. Objective of this paper: The objective of this short paper is, first to provide realistic assessment of the massive impact of the lockdown due to COVID-19 situation in Uganda from a household perspective of low income families and secondly is to propose a food relief support packages to low income households that have been hit hard by this lockdown situation. Both must be considered in the short term situation until the economy is able to bounce back in the medium term situation.
\end{abstract}




\section{Keywords}

Pandemic, COVID-19, Lockdown Measures, Government of Uganda, Households

\section{Introduction}

The coronavirus (COVID-19) pandemic outbreak has caused a global health emergency in the entire world with the US, Spain, Italy, the UK, France and Germany being the most affected global nations. What was initially seen as a largely China-centric problem is now a global crisis beyond the obvious public health crisis; the coronavirus is having a major impact on the global economy. Initially, the perception was that the COVID-19 pandemic would be localized only in the Chinese district of Wuhan but it later broke out in the whole world. The economic pain became severe as people were asked to stay at home, and the severity was felt in various sectors of the economy with travel bans affecting the aviation industry, sporting event cancellations affecting the sports industry, hospitality industry, financial sector, financial markets, events industry, entertainment industry, the prohibition of mass gatherings affecting the events and entertainment industries (Horowit, 2020; Larry Elliot, 2020).

\section{World/Global Transmission of COVID-19 Statistics}

Data collected from the worldometer on the $30^{\text {th }}$ of April 2020, show that the US had the most infected and confirmed cases of COVID-19, followed by Spain, Italy, France, the UK, Germany, Turkey and Russia. The statistics are in Table 1.

Table 1. World COVID-19 statistics on 30 $0^{\text {th }}$ April 2020.

\begin{tabular}{cccccccc}
\hline World, Other & Total Cases New Cases & $\begin{array}{c}\text { Total } \\
\text { Deaths }\end{array}$ & $\begin{array}{c}\text { New } \\
\text { Deaths }\end{array}$ & $\begin{array}{c}\text { Total } \\
\text { Recovered }\end{array}$ & Active Cases & $\begin{array}{c}\text { Serious, } \\
\text { Critical }\end{array}$ \\
\hline World & $3,236,296$ & $+18,113$ & 228,611 & +581 & $1,010,080$ & $1,997,605$ & 59,956 \\
USA & $1,064,737$ & +543 & 61,670 & +14 & 147,411 & 855,656 & 18,851 \\
Spain & 236,899 & - & 24,275 & - & 132,929 & 79,695 & 7764 \\
Italy & 203,591 & - & 27,682 & - & 71,252 & 104,657 & 1795 \\
France & 166,221 & - & 24,087 & - & 48,228 & 94,105 & 4207 \\
UK & 165,221 & - & 26,097 & - & N/A & 138,780 & 1559 \\
Germany & 161,552 & +13 & 6467 & - & 123,500 & 31,585 & 2415 \\
Turkey & 117,589 & - & 3081 & - & 44,040 & 70,468 & 1574 \\
Russia & 106,498 & +7099 & 1073 & +101 & 11,619 & 93,806 & 2300 \\
Iran & 94,640 & +883 & 6028 & +71 & 75,103 & 13,509 & 2976 \\
China & 82,862 & +4 & 4633 & - & 77,610 & 619 & 41 \\
Brazil & 79,685 & +324 & 5513 & +2 & 34,132 & 40,040 & 8318 \\
\hline
\end{tabular}

Source: Worldometer April, 30 2020. 


\section{East Africa COVID-19 Transmissions Statistics}

Statistics/Data collected from the worldometer on the East African Regional countries on the $30^{\text {th }}$ of April 2020, show that Tanzania had the most infected and confirmed cases of COVID-19 followed by Kenya and Rwanda. The statistics are in Table 2.

\section{Lock Down due to COVID-19 in Uganda}

By the time of writing this paper, there are 81 confirmed cases of COVID-19 infections in Uganda. On $22^{\text {nd }}$ March early this year Uganda confirmed its first case of COVID-19 virus. The confirmed case was a 36-year-old Ugandan male who had traveled to Dubai on March $17^{\text {th }}$ for a business trip and returned to Uganda on March 21, 2020 at around 2 am aboard Ethiopian Airlines. Subsequent to confirmation of the $1^{\text {st }}$ COVID-19 case in Uganda, the president of the Republic of Uganda, H.E. Yoweri Kaguta Museveni, took to the media to address the nation on $26^{\text {th }}$ March 2020 where he announced a ban all public means of transport and prohibited mass gathering of more than five people as well as all religious gatherings of churches and mosques. On $30^{\text {th }}$ March 2020, he addressed the nation again and in his speech he banned movement of all private cars on public roads and that is when the total local down of the country took effect in Uganda with very limited movements of people.

The honest truth about the low income household communities is that most families are struggling to put food on the table. While not admitting openly, many families struggle to put food on the table and to take care of their families. This was very true prior to COVID-19. What the pandemic has done is to accelerate the already difficult situation with the lockdown now addressed in the equation. But the lockdown has amplified existential crises such as increase in prices of basic household commodities, absence of food, unemployment, poverty and inequality (Daily Monitor, Tuesday April 28 $8^{\text {th }}, 2020$ ).

Fast Lockdown Measures introduced by the government of Uganda

The lockdown health safety measures introduced by the president of Uganda, His Excellency Gen KagutaYoweri Museveni can be divided into two categories, Public Heath Safety measures and Human Safety Control measures. The fast

Table 2. East African region COVID-19 statistics on $30^{\text {th }}$ April 2020.

\begin{tabular}{cccccccc}
\hline World, Other & Total Cases New cases & $\begin{array}{c}\text { Total } \\
\text { Deaths }\end{array}$ & $\begin{array}{c}\text { New } \\
\text { Deaths }\end{array}$ & $\begin{array}{c}\text { Total } \\
\text { Recovered }\end{array}$ & Active Cases & $\begin{array}{c}\text { Serious, } \\
\text { Critical }\end{array}$ \\
\hline World & $3,236,296$ & $+18,113$ & 228,611 & +581 & $1,010,080$ & $1,997,605$ & 59,956 \\
Tanzania & 480 & - & 16 & - & 167 & 297 & 7 \\
Kenya & 384 & - & 15 & - & 129 & 240 & 2 \\
Rwanda & 255 & - & - & - & 98 & 127 & 0 \\
Uganda & 81 & - & - & - & 52 & 29 & 0 \\
Burundi & 11 & - & 1 & - & 4 & 6 & 0 \\
\hline
\end{tabular}

Source: Worldometer April, 30 2020. 
lockdown measures introduced by the government of Uganda are in Table 3.

Response to the Government of Uganda lockdown measures. The response to the government of Uganda lockdown measures is summarized in Table 4.

\section{Method}

This paper adopted qualitative research approach, specifically the paper employed standardized/structured interview approach, an interview is generally a qualitative research technique which involves asking open-ended questions to converse with respondents and collect elicit data about a subject. The interviewer in most cases is the subject matter expert who intends to understand respondent opinions in a well-planned and executed series of questions and answers.

An interview schedule which contained structured and explicit questions was employed. According to Berg (2009) suggests that this form of interviewing is based on the premise that responses to the questions will be comparable, hence this method was deemed appropriate because the response to questions deemed

Table 3. Fast lockdown measures introduced on $30^{\text {th }}$ March 2020.

\begin{tabular}{|c|c|c|}
\hline & Type & Fast Lockdown Measures \\
\hline 1. & $\begin{array}{c}\text { Public Lockdown } \\
\text { Measures }\end{array}$ & $\begin{array}{l}\text { 1) Shutdown of all schools and all other higher learning institutions } \\
\text { both private and public. } \\
\text { 2) Shut down of air, land and sea borders. } \\
\text { 3) Ban on all public transport means including buses, passenger taxis on } \\
\text { public roads. } \\
\text { 4) Ban on all movements of private cars on public road. } \\
\text { 5) Motorcycle riders not exceeding } 2 \text { pm on public roads. } \\
\text { 6) Only trucks delivering food items and other essential vehicles like } \\
\text { Ambulances and government vehicles to be allowed on public roads }\end{array}$ \\
\hline 2. & $\begin{array}{l}\text { Human Safety } \\
\text { Control measures. }\end{array}$ & $\begin{array}{l}\text { 1) Issuing a stay at home policy. } \\
\text { 2) Enforcement of Curfew hours by the security forces from } 7 \mathrm{pm} \text { to } 6 \\
\text { am in the morning. }\end{array}$ \\
\hline
\end{tabular}

Source: Ministry of Health Website: www.health.go.ug.

Table 4. Response to the government of Uganda lockdown measures on $30^{\text {th }}$ March 2020.

\begin{tabular}{|c|c|c|c|c|c|c|c|}
\hline & $\begin{array}{l}\text { Ban on } \\
\text { foreign } \\
\text { travels }\end{array}$ & $\begin{array}{c}\text { Ban on } \\
\text { internal } \\
\text { travels }\end{array}$ & $\begin{array}{c}\text { Ban on } \\
\text { public } \\
\text { transport }\end{array}$ & $\begin{array}{c}\text { Ban on } \\
\text { mass } \\
\text { gatherings }\end{array}$ & $\begin{array}{l}\text { Closing down } \\
\text { on schools and } \\
\text { churches }\end{array}$ & $\begin{array}{c}\text { Restriction on } \\
\text { shops and } \\
\text { restaurants }\end{array}$ & Remarks \\
\hline Uganda & $\checkmark$ & $\checkmark$ & $\checkmark$ & $\checkmark$ & $\checkmark$ & $\checkmark$ & $\begin{array}{l}\text { 1) Closure of all schools and higher institutions of learning } \\
\text { on March } 20^{\text {th }} 2020 \text {. } \\
\text { 2) Banned on mass gatherings and all religious institutions } \\
\text { on } 20^{\text {th }} \text { March } 2020 \text {. } \\
\text { 3) Closure of the airport effected on } 26^{\text {th }} \text { March } 2020 \text {. } \\
\text { 4) Public transport banned for } 14 \text { days on } 26^{\text {th }} \text { March } 2020 . \\
\text { 5) President Museveni banned private cars and declared a } \\
\text { curfew on } 30^{\text {th }} \text { March } 2020 \text {. }\end{array}$ \\
\hline
\end{tabular}

Source: Daily Monitor, New Vision Local News Papers March $20^{\text {th }}$ to March $30^{\text {th }} 2020$. 
comparable between the different lockdown scenarios of before, during and after the lockdown. Using stratified sampling, 10 households were selected in each of the four divisions of Nakawa, Rubaga, Makindye, Kawempwe and Kampala central making Kampala district, two members of each household.

\section{Analysis of the data}

While interviewing the two household members from each division, an audio recording of the interview process was maintained. After the recorded Audio transcript was played for each household interviewee to confirm their actual interview responses. This helped to ensure validity of the data and interpretations made by the interviewer. Lathlearn (2006) suggests that analysis of qualitative data needs to be rigorous and systematic and how it is carried out will depend on particular chosen approach.

\section{Discussion of Results}

The results from the interview process from the selected 10 household income families from the central, Nakawa, Rubaga, Makindye and Kawempe were discussed in comparison with Average Nominal Monthly Household Income (UGX) for 2012/13 and 2016/17. The discussion of results is in Table 5 based on the statistics as at 2016/17 Uganda National Household Survey.

\section{Lockdown Average Nominal Monthly Household Income (UGX)}

The data collected was developed in subsequent themes, first data was collected, transcribed and later simplified, displayed and presented in Table 6, for purpose of portraying relationship between the Average Nominal Monthly

Table 5. Average nominal monthly household income (UGX) as at 2016/17 HH survey.

\begin{tabular}{ccc}
\hline Residence & $\mathbf{2 0 1 2 / 1 3}$ & $\mathbf{2 0 1 6 / 1 7}$ \\
\hline Rural & 242,000 & 303,000 \\
Urban & 669,500 & 703,000 \\
Sub Region & & \\
Kampala central & 918,500 & 938,000 \\
Central I: Nakawa \& Rubaga & 545,600 & 569,000 \\
Central II: Makindye \& Kawempe & 433,300 & 463,000 \\
\hline
\end{tabular}

Source: Uganda National Household Survey 2016/17.

Table 6. Monthly average nominal monthly household income (UGX).

\begin{tabular}{|c|c|c|c|c|}
\hline Residence & $\begin{array}{c}\text { Jan to March } 25^{\text {th }} 2020 \\
\text { before lockdown }\end{array}$ & Income Source & $\begin{array}{l}\text { Start of the lockdown from } \\
\text { March } 26^{\text {th }} 2020 \text { to date }\end{array}$ & Income Source \\
\hline Kampala central & $1,005,500$ & \multirow{3}{*}{$\begin{array}{l}\text { From formal and } \\
\text { informal employment }\end{array}$} & Approx 200,000 & \multirow{3}{*}{$\begin{array}{l}\text { From individual } \\
\text { savings and close } \\
\text { family members }\end{array}$} \\
\hline Central I: Nakawa \& Rubaga & 650,000 & & Approx 100,000 & \\
\hline Central II: Makindye \& Kawempe & 500,300 & & Approx 50,000 & \\
\hline
\end{tabular}

Source: Own Interview process $30^{\text {th }}$ April 2020. 
Household Income (UGX) of Uganda for 2012/13 \& 2016/17 and the Average Nominal Monthly income of the months of January to $20^{\text {th }}$ March 2020 before the lockdown and $26^{\text {th }}$ March to date 2020 during the lockdown. After possible explanations, conclusions and recommendations were made from the data.

\section{Conclusion}

The COVID-19 pandemic has affected the supply side of Uganda's economy with factories, hotels, shops and offices closed due to the lockdown which has heavily impacted on daily, weekly and monthly wages of both the formal and informal household workers who are unable at the moment to engage in any productive trade as markets are closed matched with public transport restrictions. Similarly, on the demand side of the economy people have been locked home with no customers, no tourists, no shoppers and no passengers hence significantly affecting the daily, weekly and monthly household incomes.

\section{Recommendations}

Government should continue providing relief food packages to the low income household families that have been significantly hit with the nationwide lockdown situation, Relief food packages must be considered in the short term situation until the economy is able to bounce back in the medium term situation.

\section{Limitations of the Study}

The lockdown measures taken by government of Uganda presented in this study, the data collected and the analysis in this study are limited to the period of analysis, that is, up to $30^{\text {th }}$ April 2020.

\section{Conflicts of Interest}

The authors declare no conflicts of interest regarding the publication of this paper.

\section{References}

Berg (2009). Qualitative Research Methods for the Social Sciences (pp. 101-157). Boston: Allyn \& Bacon.

Daily Monitor and New Vision Local News Papers 20th to 30th March, 2020.

East African Region COVID-19 Statistics as at 30th April 2020; World Meter April, 30th 2020.

Fast Lockdown Measures Introduced. http://www.health.go.ug

Horowit, J. (2020). The Global Coronavirus Recession Is Beginning. CNN. Media Report. https:/edition.cnn.com/2020/03/16/economy/global-recession-coronavirus/index.html

Larry Elliot, L. (2020). Prepare for the Corona Virus Global Recession. The Guardian, Media Report.

https://www.theguardian.com/business/2020/mar/15/prepare-for-the-coronavirus-glob al-recession 
R. Wemesa et al.

Lathlearn (2006). Analysis of Qualitative Data.

Ministry of Health Website. http://www.health.go.ug

Response to the Government of Uganda Lockdown Measures. http://www.health.go.ug 